\title{
Pengaruh Pelabuhan Perikanan Pantai Tegalsari terhadap Kesejahteraan Pekerja
}

\author{
Arief Diantoro $^{1}$ \\ Jurusan Perencanaan Wilayah dan Kota \\ Fakultas Teknik, Universitas Diponegoro, Semarang \\ Mussadun \\ Jurusan Perencanaan Wilayah dan Kota \\ Fakultas Teknik, Universitas Diponegoro, Semarang \\ Artikel Masuk : 8 Januari 2014 \\ Artikel Diterima : 6 Februari 2014
}

\begin{abstract}
Abstrak: Keberadaan Pelabuhan Perikanan Pantai (PPP) Tegalsari erat kaitannya dengan kehidupan masyarakat sekitar sebagai penunjang kesejahteraan melalui kesempatan lapangan pekerjaan. Namun, terdapat permasalahan kesenjangan ekonomi antara pekerja buruh dan pemilik usaha dengan modal besar sehingga kesenjangan pendapatan masih menjadi isu yang penting. Penelititan ini bertujuan untuk menggali aktivitas di PPP Tegalsari dan pengaruhnya terhadap kesejahteraan pekerja. Penelitian menggunakan pendekatan kualitatif dan kuantitatif. Pendekatan kuantitatif untuk melihat aktivitas unggulan dan pengaruhnya terhadap kesejahteraan pekerja dan pendekatan kualitatif untuk melihat aktivitas yang terjadi. Temuan studi menjelaskan terdapat 4 aktivitas utama di PPP Tegalsari, yaitu pelayanan jasa, perdagangan, pekerja penggiat usaha perikanan, dan penunjang. Aktivitas unggulan adalah pelayanan jasa dengan skor 16. Sementara itu, pengaruh pelabuhan terhadap kesejahteraan paling besar terdapat pada aktivitas pelayanan jasa dengan skor 435.Studi menekankan bahwa aktivitas berpengaruh terhadap tingkat pendapatan dan tingkat pendapatan berbanding lurus dengan tingkat kesejahteraan pekerja. Untuk itu, rekomendasi kepada pemerintah adalah agar mengupayakan aktivitas pelayanan jasa sebagai aktivitas unggulan untuk pengembangan PPP Tegalsari dan meningkatkan aktivitas lainya agar terpenuhi kesejahteraan masyarakat yang merata di semua aktivitas. Sementara itu, rekomendasi bagi pihak pengusaha atau swasta adalah memberikan perhatian kepada para pekerja untuk meningkatkan perekonomian masyarakat sekitar.
\end{abstract}

Kata Kunci: aktivitas unggulan, pengaruh terhadap kesejahteraan pekerja, PPP Tegalsari

\begin{abstract}
The existence of Pelabuhan Perikanan Pantai Tegalsari (PPP Tegalsari) or Tegalsari Fishing Harbor (TFH) is closely linked to the local livelihood where the job opportunities available to the local residents in pursuit of better living standards. However, there are economic disparities between the workers and business owners so that income inequality remains a critical issue here. This study aims to explore the activities in TFH and their influences on the workers' welfare. This study applies both quantitative and qualitative approaches. The former is applied for identifying the leading sectors and their impacts on the worker's welfare, and the latter is to explaining their activities comprehensively. The findings demonstrate that there are four main activities in TFH: services, trade, fishing enterprises, and supporting activities. The service activities are the leading sector with a score of 16 .
\end{abstract}

\footnotetext{
${ }^{1}$ Korespondensi Penulis: Jurusan Perencanaan Wilayah dan Kota, Universitas Diponegoro, Semaran Email: ariefdiantoro@gmail.com
} 


\section{Pengaruh Pelabuhan Perikanan Pantai Tegalsari terhadap Kesejahteraan Pekerja}

Meanwhile, the highest influencing activity which contributes to the workers' welfare is service activities with a score of 435. The study concludes that the activities in the TFH positively correlate to their income level which in turn contributes to their welfare improvement. Therefore, the government is recommended to providing greater service supports and the associated activities in order to create more equitable opportunities for all sectors. As for the business owners and private sectors, they are encouraged to pay more attention to their workers' welfare from which the local economy could be accelerated.

Keywords: leading activity, the influence on the workers welfare, PPP Tegalsari

\section{Pendahuluan}

Sektor perikanan adalah sektor yang cukup menjanjikan. Pengembangan sektor perikanan memberikan dampak positif pada perekonomian termasuk diantaranya adalah lapangan pekerjaan bagi masyarakatnya (Eggert \& Greaker, 2009). Ini dikarenakan sektor perikanan sarat nilai ekonomis. Pemanfaatan peluang usaha dan kesempatan kerja akan meningkatkan pendapatan yang akan digunakan untuk meningkatkan kesejahteraan masyarakat dengan memanfaatkan produk-produk dan jasa yang disediakan oleh masyarakat itu sendiri. Kesejahteraan nelayan berkorelasi dengan aktivitas perikanan dan keuntungan yang didapatkan (Rees, Rodwell, Searle, \& Bell, 2013).

Menurut Suherman (2010) bahwa pembangunan pelabuhan perikanan bertujuan untuk membangun masyarakat pesisir guna meningkatkan kesejahteraan masyarakatnya, khususnya masyarakat nelayan. Pelabuhan berfungsi sebagai wadah transaksi antar nelayan dengan aktor perikanan lainnya. Keberadaan pelabuhan berdampak pada terbukanya lapangan kerja baru untuk melayani kebutuhan para pegawai/pekerja pelabuhan (Suherman \& Dault, 2009). Kondisi ini menunjukkan bahwa wadah para nelayan dan pekerja terkait perikanan berupa pelabuhan perikanan pantai penting keberadaannya sebagai sarana penunjang kesejahteraan masyarakat.

Sebagai kota yang berbatasan langsung dengan Laut Jawa, Kota Tegal memiliki PPP Tegalsari sebagai pemenuh kebutuhan aktivitas perikanan. Berkembangnya PPP Tegalsari meningkatkan perekonomian daerah dengan produksi hasil laut sebesar $29.516 .013 \mathrm{~kg}$ pada tahun 2012. Hasil penelitian Yahya, Rosyid, dan Suherman (2012) dan Nurdyana, Rosyid, dan Boesono (2013) menunjukkan bahwa kelengkapan fasilitas pelabuhan berkaitan dengan peningkatan hasil produksi tangkapan ikan. Penelitian Yahya et al. (2012) dan Nurdyana et al. (2013) di PPP Tegalsari menunjukkan bahwa PPP Tegalsari telah memiliki fasilitas dasar, fungsional, dan penunjang dalam kondisi cukup baik. Namun demikian, aktivitas perikanan di PPP Tegalsari dihadapkan pada masalah kesenjangan kesejahteraan antara pekerja dan pengusaha pemilik modal yang besar menjadi permasalahan yang coba diangkat dari penelititan ini. Kesejahteraan nelayan juga berkorelasi dengan value chain aktivitas perikanan mulai dari proses hingga penjualan (McEvoy, Brandt, Lavoie, \& Anders, 2009).

Permasalahan tersebut dikarenakan terdapatnya ketidakpedulian pengusaha terhadap kesejahteraan para pekerja dan juga tidak disiplinnya para pengusaha dalam melakukan retribusi secara jujur kepada pihak pelabuhan. Keberadaan perikanan kelautan dapat menjadi sebuah tulang punggung suatu daerah jika dapat dikelola dengan baik. Penyelewengan dan ketidakpedulian pengusaha perikanan dalam melakukan pembayaran retribusi dapat mejadi ancaman hilangnya pemasukan daerah (Standing, 2008).

Pekerjaan pada sektor perikanan dan kelautan kedepannya diharapkan akan tetap berjalan melihat potensi yang dimiliki sektor kelautan dan perikanan. Terdapat beberapa faktor yang mempengaruhi pekerjaan pada sektor perikanan dan kelautan seperti kestabilan hasil melaut, keamanan, keselamatan, jadwal pekerjaan yang tidak teratur, jauh 
dari rumah, dan jaminan hari tua. Faktor-faktor tersebut dapat menjadikan pertimbangan masyarakat pesisir untuk meninggalkan pekerjaan mereka pada sektor perikanan dan kelautan (Johnsen \& Vik, 2013).

Daerah pesisir adalah salah satu daerah yang tertinggal dilihat dari sisi perekonomian dan kesejahteraan masyarakatnya. Pemerintah memiliki peran yang cukup kuat dalam pengambilan kebijakan dalam upaya mengentaskan kemiskinan di daerah pesisir (Amarasinghe, 2005). Aktivitas pelabuhan serta dampaknya perlu dirumuskan mengingat pentingnya hal tersebut dalam perkembangan pelabuhan serta memastikan aktivitas perikanan kelautan tetap berlangsung demi menjaga kebutuhan akan perikanan serta pekerjaan bagi masyarakat guna menunjang kesejahteraan pekerja pelabuhan. Untuk itu, penelitian bertujuan untuk menggali aktivitas di PPP Tegalsari dan pengaruhnya terhadap kesejahteraan pekerja Penelitian diharapkan dapat menghasilkan sebuah rumusan tentang aktivitas unggulan sebagai masukan kepada pemerintah, swasta, serta pihak terkait dalam menentukan kebijakan dalam upaya mengembangkan pelabuhan dan meningkatkan kesejahteraan pekerja pelabuhan.

\section{Metode Penelitian}

Pendekatan penelitian yang digunakan dalam penelitian ini adalah pendekatan campuran yaitu kualitatif dan kuantitatif, dimana kualitatif digunakan untuk mengatahui aktivitas pelabuhan dan kuantitatif untuk mengetahui aktivitas unggulan dan pengaruh pelabuhan terhadap kesejahteraan. Teknik pengumpulan data melalui dua cara, yaitu teknik pengumpulan data primer melalui observasi lapangan dan kuesioner, serta teknik pengumpulan sekunder melalui kajian dokumen. Penetapan ukuran sampel didasarkan atas pertimbangan Roscoe yaitu bila Sampel dibagi dalam kategori, maka jumlah anggota sampel tiap kategori minimal 30 (Sugiyono, 2008). Berdasarkan pendapat di atas maka sampel yang digunakan dalam penelitian ini adalah 30 setiap aktivitasnya sebagaimana terjelaskan di Tabel 1. Analisis dalam penelitian, yaitu:

1. Analisis Aktivitas Pelabuhan Perikanan Pantai (PPP) Tegalsari

Analisis yang digunakan dalam mencapai sasaran tersebut adalah dengan mempelajari literatur yang berhubungan dengan kegiatan yang terjadi di kawasan pelabuhan. Berdasarkan beberapa literatur tersebut kemudian akan dijadikan sebagai acuan dalam menentukan aktivitas yang akan menjadi obyek penelitian. Keberadaan literatur sebagai pedoman sebagai acuan peneliti untuk mengetahui aktivitas yang berpengaruh bagi kesejahteraan pekerja dan dilengkapi dengan hasil wawancara yang dilakukan kepada pihak yang terkait dan keberadaan aktivitas pelabuhan dan juga observasi langsung. Hasil dari analisis tersebut adalah aktivitas yang menjadi fakus dalam penelitian dan melakukan analsis berikutnya.

2. Analisis Rata-rata Pendapatan Pekerja

Berdasarkan analisis pada sasaran pertama bahwa didapatkan aktivitas yang terjadi tergolong ke dalam 4 kelompok aktivitas utama seperti aktivitas pelayanan jasa, aktivitas perdagangan, aktivitas pekerja penggiat usaha perikanan, dan aktivitas penunjang. setelah mendapatkan aktivitas tersebut sampel penelitian akan disebar merata pada setiap aktivitas tersebut, berikut pembagian sampel di setiap aktivitas:

Pendekatan penelitian yang dilakukan pada analisis ini yaitu kuantitatif dengan menggunakan metode deskriptif statistik, yaitu peneliti mencoba menggambarkan rata-rata pendapatan responden disetiap aktivitas berdasarkan dari hasil kuesioner. Kebutuhan data pada sasaran tersebut adalah data primer yang didapatkan dengan cara menyebar kuesioner untuk mengetahui informasi tentang pendapatan responden setiap bulannya yang berasal dari aktivitas pelabuhan. Analisis yang dilakukan dengan menggunakan statistik deskriptif berdasarkan hasil kuesioner yang disebar kepada responden. Metode 


\section{Pengaruh Pelabuhan Perikanan Pantai Tegalsari terhadap Kesejahteraan Pekerja}

pembobotan dilakukan dalam analisis tersebut untuk melihat skor yang dimiliki setiap masing-masing aktivitas, dimana skor 4 dengan rata-rata tertinggi skor 1 untuk rata-rata pendapatan terendah.

Tabel 1. Jumlah Pengambilan Sampel

\begin{tabular}{cccc}
\hline Jenis Aktivitas & Aktivitas & Sampel & Jumlah Sampel \\
\hline \multirow{3}{*}{ Pelayanan Jasa } & Becak Ikan & 12 & \\
& Gerobak Ikan & 10 & 30 \\
& Bongkar Muat & 5 & \\
& Juri Timbang & 3 & \\
Pekerja Penggiat Usaha Perikanan & Fillet & 20 & \\
& Anak Buah Kapal & 3 & 30 \\
& Ikan Kering & 5 & \\
& Tepung Ikan & 2 & \\
& DeBot Es Batu & 6 & \\
& Bakul Ingser & 6 & \\
Perdagangan & Debot Ikan & 15 & \\
& Debot Air Bersih & 3 & \\
& Ruko Swadana & 9 & \\
& Toilet Umum & 1 & \\
& Kios Pedagang Swadana & 10 & \\
& Kios Pedagang & 10 & \\
\hline
\end{tabular}

3. Analisis Kesempatan Menabung

Pendekatan penelitian yang dilakukan pada analisis ini yaitu kuantitatif dengan menggunakan metode deskriptif statistik, yaitu peneliti mencoba menggambarkan rata-rata pendapatan responden disetiap aktivitas berdasarkan dari hasil kuesioner. Kesempatan menabung yang digunakan dalam penelititan ini adalah dengan melihat seberapa besar selisih pendapatan dan pengeluaran yang dimiliki oleh responden, karena semakin besar selisih pendapatan dengan pengeluaran maka akan semakin besar pula kesempatannya dalam menabung.

Metode pembobotan dilakukan dengan cara melihat jumlah kesempatan menabung responden atau nilai selisih antara pendapatan dan pengeluaran pada setiap aktivitasnya. Pedoman pembobotan yaitu skor 4 untuk aktivitas dengan kesempatan menabung atau selisih nilai pendapatan dan pengeluaran tinggi hingga skor 1 untuk aktivitas dengan kesempatan menabung paling rendah.

4. Analisis Kesempatan Bekerja

Pendekatan penelitian yang dilakukan pada analisis ini yaitu kuantitatif dengan menggunakan metode deskriptif statistik, yaitu peneliti mencoba menggambarkan rata-rata pendapatan responden disetiap aktivitas berdasarkan dari hasil kuesioner. Kebutuhan data dalam sasaran tersebut adalah informasi tentang asal responden diamana terdapat dua kategori yaitu berasal dari daerah sekitar dan berasal dari luar daerah.

Mengetahui kesempatan bekerja bagi masyarakat sekitar yaitu dengan cara mempersentasekan asal pekerja dari daerah sekitar sebagai dasar pengambilan bobot nilai di setiap aktivitasnya. Pembobotan yang dilakukan adalah dengan cara semakin besar jumlah responden berasal dari daerah sekitar semakin besar skor yang didapatkan aktivitas tersebut.

5. Analisis Tingkat Kesejahteraan

Analisis tersebut berdarakan hasil kuesioner yang disebarkan kepada responden di setiap aktivitas. Kuesioner tersebut mengenai 13 indikator kesejahteraan. Indikator 
kesejahteraan terdiri dari 5 pilihan dimana pilihan tersebut dari A sampai E. Diasumsikan bahwa untuk pilihan A memiliki skor nilai sebesar 1 dan begitu seterusnya sampai pilihan E memiliki nilai skor 5. Asumsi tersebut kemudian dimasukan kedalam rekap kuesioner maka akan di dapat bahwa nilai terendah untuk skor total keseluruhan 13 indikator tersebut maka nilai minimal dari indikator adalah 13 dan nilai maksimal kesejahteraan adalah 65. Berdasarkan nilai tersebut tingkat kesejahteraan dibagi menjadi tingkat yaitu tingkat I atau rendah dengan nilai (13-30), tingkat II atau sedang dengan nilai (31-48), dan tingkat III atau tinggi dengan nilai (49-65). Asumsi tersebut menjadi acuan untuk menentukan urutan aktivitas dengan skor tertinggi hingga terendah.

6. Analisis Aktivitas Unggulan

Analisis aktivitas unggulan ditentukan berdasarkan analisis sebelumnya yaitu analisis rata-rata pendapatan, analisis kesempatan menabung, analisis kesempatan bekerja, analisis tingkat kesejahteraan. Penentuan aktivitas berdasarkan skor tertinggi hingga skor terendah.

7. $\quad$ Analisis Pengaruh PPP Tegalsari Terhadap Kesejahteraan Pekerja

Melakukan pembandingan nilai rata-rata indikator kesejahteraan pada kateogori awal (awal tahun 1990an/awal bekerja) dan sekarang untuk melihat seberapa besar perubahan tingkat kesejahteraan para responden di setiap aktivitas.

\section{Hasil Pembahasan}

\section{Analisis Aktivitas Pelabuhan Perikanan Pantai (PPP) Tegalsari}

Berdasarkan aktivitas terpilih dilihat dari kajian literatur dan wawancara kepada narasumber, kemudian akan dikelompokan kedalam empat jenis aktivitas utama di dalam PPP Tegalsari. Aktivitas utama dalam PPP Tegalsari yaitu pelayanan jasa, aktivitas perdagangan, aktivitas pekerja penggiat usaha perikanan serta aktivitas penunjang.

Aktivitas pelayanan jasa adalah aktivitas yang menjadi faktor keberhasilan dalam kegiatan pelabuhan dari hulu hingga hilir. Aktivitas tersebut terdiri dari aktivitas becak ikan, gerobak ikan, aktivitas juru timbang, dan aktivitas bongkar muat. Aktivitas perdagangan terbagi menjadi dua bagian dimana aktivitas hulu terdiri dari aktivitas kebutuhan melaut seperti aktivitas pekerja debot es batu dan aktivitas debot air bersih, serta pada aktivitas hilir terdiri dari aktivitas pekerja debot ikan dan aktivitas bakul ikan dengan skala kecil. Aktivitas pekerja penggiat usaha perikanan terdiri dari aktivitas pekerja industri fillet, aktivitas pekerja industri ikan kering, aktivitas industri tepung ikan, dan anak buah kapal.

Keberadaan Pelabuhan Perikanan berdampak pada terbukanya lapangan kerja baru untuk melayani kebutuhan para pegawai/pekerja pelabuhan. Berdasarkan penjelasan di atas, keberadaan pelabuhan perikanan pantai Tegalsari juga terdapat aktivitas penunjang. Informasi yang didapatkan dari profil PPP Tegalsari dan diperkuat oleh narasumber yaitu kepala pelabuhan, di dapatkan aktivitas penunjang yang terjadi di kawasan PPP Tegalsari adalah aktivitas ruko swadana, penjga toilet umum, kios pedagang swadana, dan kios pedagang.

Gambar 1 memperlihatkan aktivitas hulu hilir di PPP Tegalsari. Berdasarkan penjelasan di Gambar 1 terlihat bahwa aktivitas pelayanan jasa tersebar di setiap proses pelabuhan dari hulu hingga hilir. Aktivitas perdagangan terdapat pada aktivitas hulu yaitu aktivit as debot es batu dan debot air bersih sebagai pemenuhan kebutuhan melaut, serta aktivitas debot ikan dan bakul ingser sebagai aktivitas hilir dimana aktivitas tersebut menjual ikan hasil melaut. Aktivitas pekerja penggiat usaha perikanan dengan keterangan berwarna biru terdiri dari pekerja industri fillet, ikan kering, dan tepung ikan termasuk kedalam kategori aktivitas hilir sedangkan aktivitas para pekerja kapal atau anak buah kapal 


\section{Pengaruh Pelabuhan Perikanan Pantai Tegalsari terhadap Kesejahteraan Pekerja}

terdapat pada aktivitas hulu. Aktivitas penunjang sebagai aktivitas pelengkap pada kegiatan PPP Tegalsari dengan keterangan berwarna kuning terdapat pada fasilitas penunjang yaitu ruko swadana, toilet umum, kios pedangan, dan kios pedagang. Aktivitas tersebut terdiri dari bermacam-macam jenis kegiatan dari penjual perlengkapan memancing hingga warung makan untuk menyediakan kebutuhan para pekerja.



\section{Gambar 1. Aktivitas Hulu-Hilir PPP Tegalsari}

\section{Analisis Rata-Rata Pendapatan}

Pendapatan yang menjadi fokus dalam penelitian adalah pendapatan responden yang berasal dari bekerja di kawasan PPP Tegalsari. Pendapatan merupakan nilai maksimum yang dapat dikonsumsi seseorang sama pada dalam suatu periode pada akhir periode (Rustam, 2002). Sedangkan menurut BPS (2011) pendapatan adalah sesuatu yang dibayarkan sebagai pengganti karena terjadinya faktor-faktor produksi dalam jangka waktu tertentu dan dapat berupa sewa, upah atau gaji, bunga uang ataupun laba.

Berdasarkan analisis didapatkan rata-rata pendapatan responden berbeda di setiap aktivitasnya. Berdasarakan hasil analisis aktivitas pelayanan jasa memiliki jumlah rata-rata pendapatan terbesar dengan nominal sebesar Rp 5.240.000,00 mendapatkan skor tertinggi yaitu 4, aktivitas penunjang dengan rata-rata pendapatan sebesar Rp 3.787.333,00 memiliki skor 3, aktivitas perdagangan denan rata-rata sebesar Rp 2.381.667,00 mendapatkan skor 2, sedangkan aktivitas pekerja penggiat usaha dengan rata-rata terendah yaitu sebesar Rp 1.811.667 mendapatkan skor terendah. Hasil dari analisis tersebut sebagai pedoman untuk melakukan pembobotan di setiap aktivitasnya dengan nilai tertinggi adalah 4 dan terendah adalah 1. Aktivitas pelayanan jasa memiliki rata-rata pendapatan sebesar Rp 5.240.000,00 mendapatkan skor tertinggi yaitu 4, aktivitas penunjang dengan rata-rata pendapatan sebesar Rp 3.787.333,00 memiliki skor 3, aktivitas perdagangan dengan rata-rata sebesar Rp 2.381.667,00 mendapatkan skor 2, sedangkan aktivitas pekerja penggiat usaha dengan rata-rata terendah yaitu sebesar Rp 1.811.667,00 mendapatkan skor terendah.

Gambar 2 menjelaskan perbedaan rata-rata pendapatan melalui gradasi warna dengan asumsi semakin gelap warna maka semakin tinggi pendapatan yang diperoleh pekerja pada aktivitas tersebut. Persebaran pendapatan pada aktivitas PPP Tegalsari dengan jumlah tertinggi terdapat pada sektor pelayanan jasa termasuk diantaranya adalah aktivitas becak ikan, gerobak ikan, dan juru timbang memiliki warna yang paling tebal. Keberadaan aktivitas pelayanan jasa memiliki nilai pendapatan tinggi karena penghasilan yang diperoleh responden pada sektor tersebut berpendapatan hampir Rp 200,00/ hari. 
Aktivitas dengan pendapatan rendah terdapat pada aktivitas penggiat usaha perikanan termasuk di dalamnya adalah aktivitas anak buah kapal, pekerja bongkar muat, pekerja debot ikan, penjaga toilet umum dan pelaku aktivitas pada kios pedagang. Rendahnya tingkat pendapatan pada aktivitas tersebut dikarenakan upah yang diberikan kepada aktivitas penggiat usaha perikanan bersifat harian dan hanya sebatas pada upah minum regional daerah.

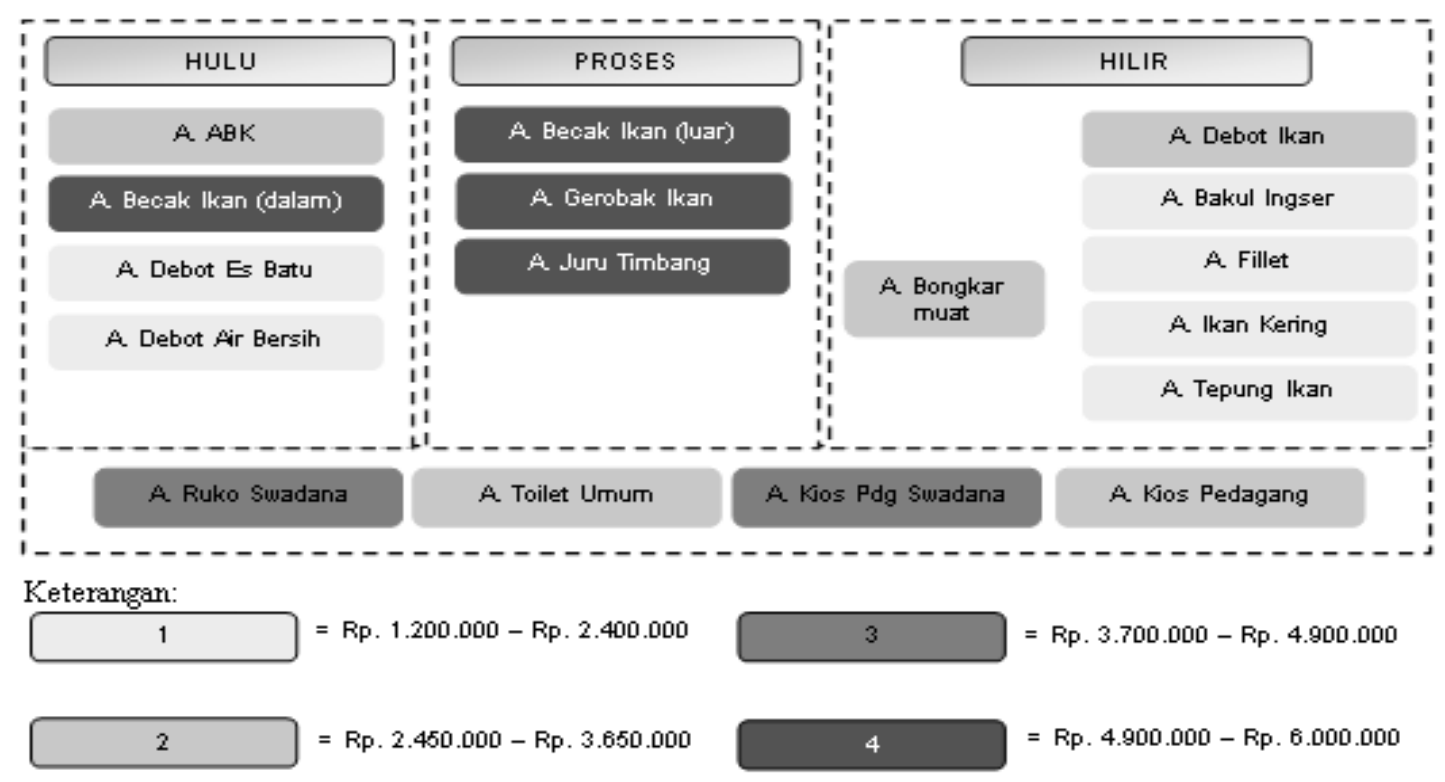

\section{Gambar 2. Pendapatan Tiap Aktivitas}

\section{Analisis Kesempatan Menabung}

Tabungan sebagaimana dikemukakan oleh Pass dan Lowes (1994) adalah bagian pendapatan yang diterima masyarakat yang secara sukarela tidak digunakan untuk konsumsi. Masyarakat menggunakan bagian dari pendapatan yang tidak dikonsumsi tersebut untuk beberapa tujuan: disimpan saja tanpa digunakan, disimpan atau ditabung pada lembaga-lembaga keuangan, dipinjamkan kepada anggota masyarakat lainnya, serta digunakan untuk penanaman modal yang produktif. Penjelasan lebih sederhana tabungan adalah bagian pendapatan yang diterima oleh maayarakat dan tidak digunakan untuk keperluan konsumsi (Sukirno, 2000). Kesempatan menabung dalam analisis ini melihat selisih pendapatan reponden yang telah dikurangi oleh faktor produksi.

Berdasarkan hasil penghitungan, didapatkan aktivitas pelayanan jasa memiliki kesempatan menabung dengan nominal sebesar Rp 2.276.667,00, aktivitas penunjang memiliki kesempatan menabung dengan nominal sebesar Rp 1.266.667,00, aktivitas perdagangan memiliki kesempatan menabung dengan nominal sebesar Rp 758.333,00, aktivitas pekerja penggiat usaha perikanan memiliki kesempatan menabung dengan nominal sebesar Rp 261.667,00. Hasil perhitungan sebagai pedoman untuk melakukan pembobotan pada setiap aktivitasnya dimana aktivitas pelayanan jasa mendapatkan skor tertinggi yaitu 4, aktivitas penunjang memiliki skor 3, aktivitas perdagangan memiliki skor 2, dan aktivitas pekerja penggiat usaha perikanan memiliki skor 1 .

Gambar 3 menjelaskan perbedaan kesempatan menabung melalui gradasi warna dengan asumsi semakin gelap warna maka semakin tinggi kesempatan menabung yang dimiliki oleh pekerja pada aktivitas tersebut. Berdasarkan penjelasan gambar di atas terlihat 


\section{Pengaruh Pelabuhan Perikanan Pantai Tegalsari terhadap Kesejahteraan Pekerja}

aktivitas pelayanan jasa seperti contohnya aktivitas becak ikan, gerobak ikan, dan juru timbang memiliki warna yang paling gelap yaitu berarti aktivitas tersebut memiliki kesempatan menabung yang paling tinggi bila dibandingkan dengan aktivitas lainnya. Kategori dengan nominal kesempatan menabung terendah terdiri dari aktivitas ABK, pekerja debot es batu, debot air bersih, bongkar muat, fillet, ikan kering, tepung ikan dan pedagang ikan kecil atau bakul ingser serta dari sektor penunjang yaitu penjaga toilet umum dan pelaku aktivitas pada kios pedagang. Analisis kesempatan menabung melihatkan bahwa tingkat pendapatan seseorang berbanding lurus terhadap kesempatan menabung yang dimilikinya. Hasil dari analisis dapat menjadikan sebuah pedoman bahwa peningkatan pendapatan dapat meningkatkan kesempatan menabung sesorang untuk dapat memenuhi atau menjamin kesejahteraan di kemudian hari.

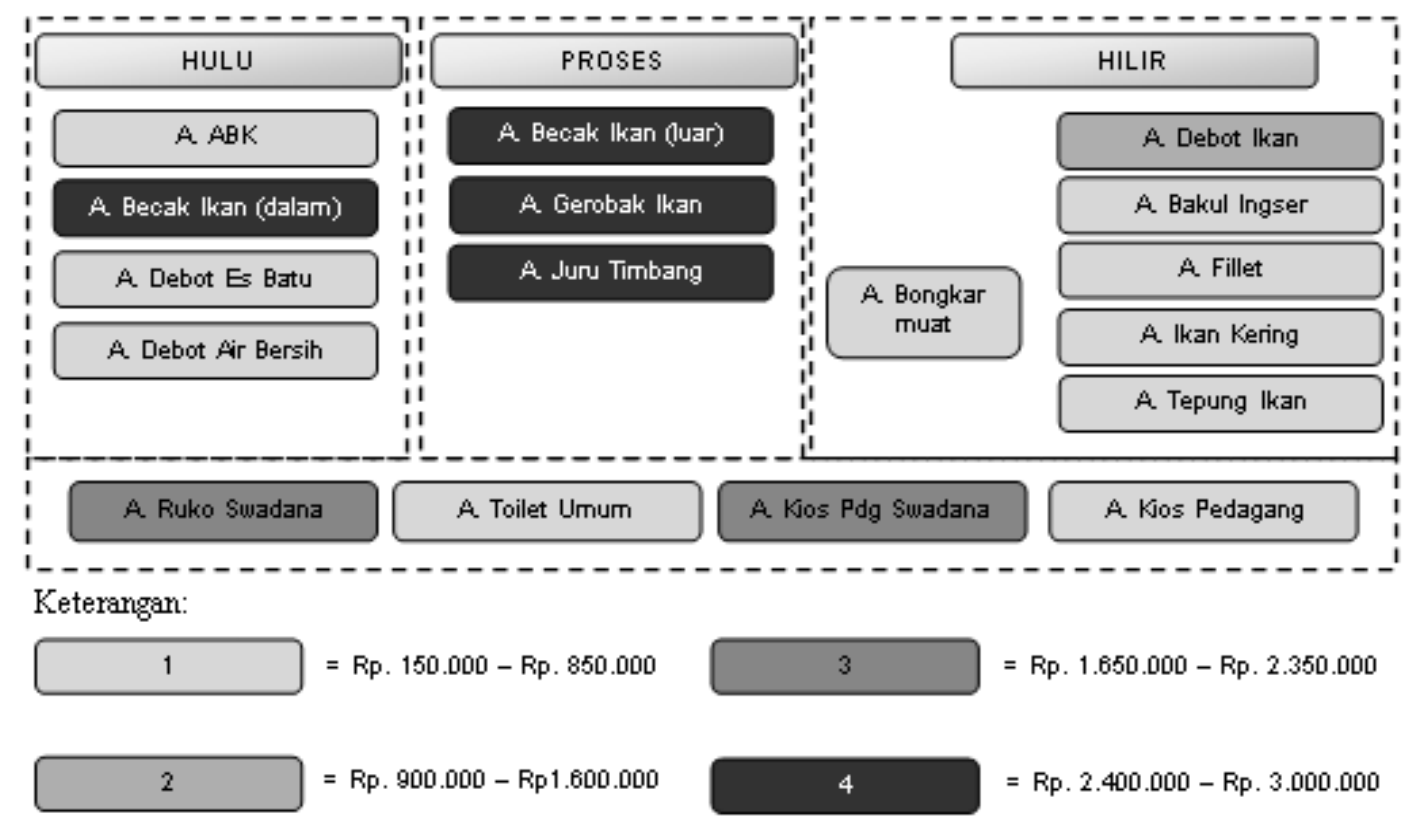

\section{Gambar 3. Kesempatan Menabung Tiap Aktivitas}

\section{Analisis Kesempatan Bekerja}

Keberadaan aktivitas pelabuhan di dalam wilayah studi secara langsung maupun tidak langsung dapat membuka peluang bagi masyarakat untuk bekerja di dalam pelabuhan. Analisis kesempatan bekerja yang dimaksud dalam penelitian ini adalah melihat seberapa besar jumlah pekerja yang berasal dari daerah sekitar PPP Tegalsari. Analisis yang dilakukan berdasarkan dari hasil kuesioner asal pekerja yang menjadi responden setiap aktivitas yang terjadi di dalam kawasan PPP Tegalsari. Gambar 4 menunjukkan kesempatan bekerja tiap aktivitas. 


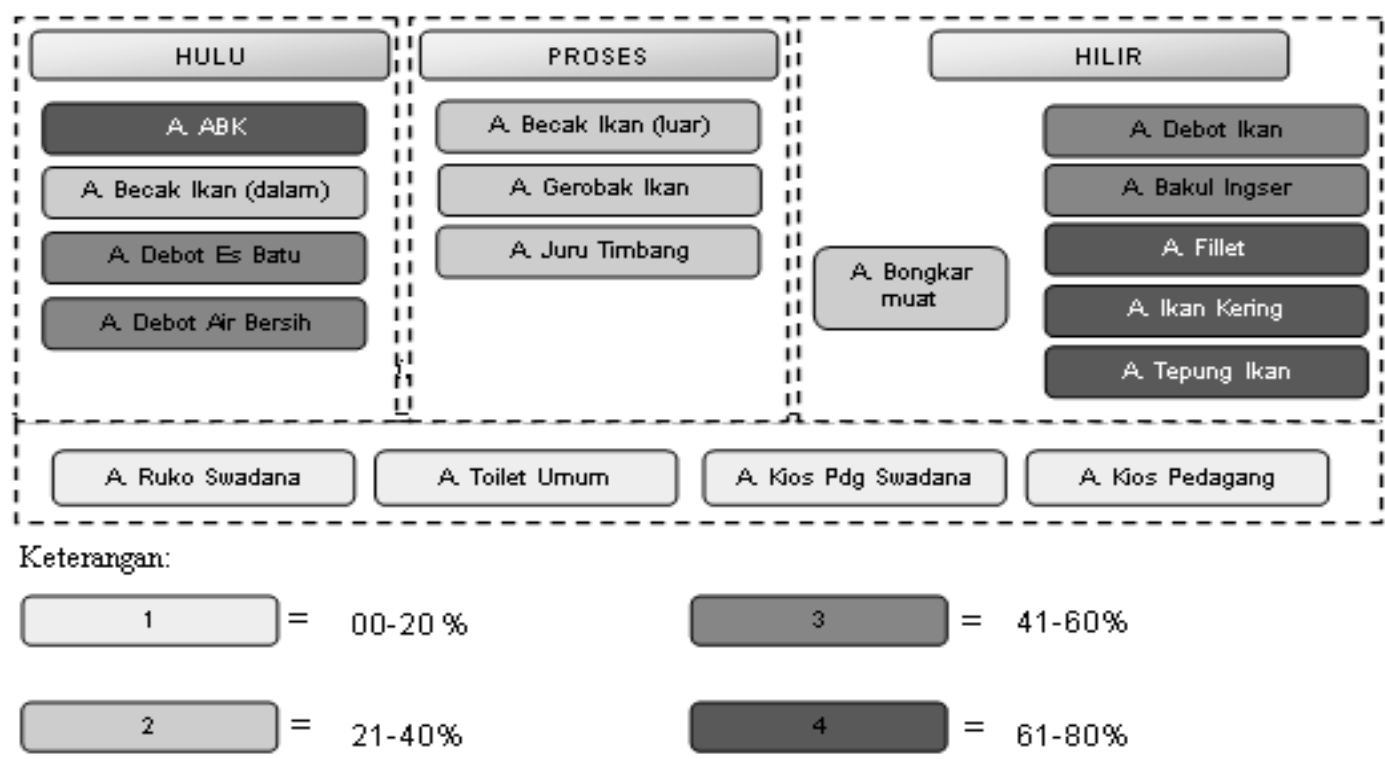

Gambar 4. Kesempatan Bekerja Tiap Aktivitas

\section{Analisis Tingkat Kesejahteraan}

Berdasarkan indikator kesejahteraan, diasumsikan bahwa untuk pilihan A memiliki skor nilai sebesar 1 dan begitu seterusnya sampai pilihan E memiliki nilai skor 5 . Asumsi tersebut kemudian dimasukan kedalam rekap kuesioner maka akan di dapat bahwa nilai terendah untuk skor total keseluruhan 13 indikator tersebut adalah 13 dan tertinggi adalah 65. Untuk mempermudah klasifikasi, kesejahteraan dibagi menjadi tiga tingkatan yaitu tingkat I atau rendah dengan nilai (13-30), tingkat II atau sedang dengan nilai (31-48), dan tingkat III atau tinggi dengan nilai (49-65).

Aktivitas pelayanan jasa terdiri dari 1 responden pada tingkat I, 26 responden pada tingkat II, dan 3 responden pada tingkat III. Pada aktivitas perdagangan terdiri dari 15 responden pada tingkat I, 15 responden pada tingkat II, dan tidak ada responden pada tingkat III. Aktivitas pekerja penggiat usaha perikanan terdiri dari 18 responden pada tingkat I, 12 responden pada tingkat II, dan tidak ada responden pada tingkat III. Aktivitas penunjang terdiri dari 10 responden pada tingkat I, 11 responden pada tingkat II, dan 9 responden pada tingkat III.

Gambar 5. menjelaskan tingkat kesejahteraan tiap aktivitas. Hasil analisis menjelaskan aktivitas pelayanan jasa memiliki skor tertinggi dengan terdapat responden tingkat I berjumlah 10 orang, tingkat II berjumlah 11 orang dan tingkat III berjumlah 9 orang. Indikator pendapatan merupakan indikator pendapatan dengan nilai skor yaitu 145 dan apabila dilihat pada diagram batang termasuk kedalam kategori sangat baik. Aktivitas dengan tingkat kesejahteraan terendah yaitu terdapat pada aktivitas penggiat usaha perikanan dengan responden tingkat I berjumlah 18 orang, tingkat II berjumlah 12 orang dan tidak terdapat responden dengan kesejahteraan tingkat III.

Hasil analisis memperlihatkan bahwa indikator berpengaruh pada setiap aktivitas berbeda, pada aktivitas pelayanan jasa indikator pendapatan menjadi indikator penyumbang nilai terbesar pada tingkat kesejahteraan. Pada aktivitas perdagangan indikator pemenuhan kebutuhan pendidikan memiliki nilai tertinggi dengan nilai 116 atau termasuk kedalam kategori baik. Indikator kemampuan memenuhi kebutuhan tempat tinggal pada aktivitas pekerja penggiat usaha perikanan memiliki nilai tertinggi yaitu 124 
termasuk kedalam kategori baik. Pada aktivitas penunjang indikator pemenuhan kebutuhan trasnportasi memiliki nilai tertinggi dengan nilai 124 atau termasuk kategori baik.

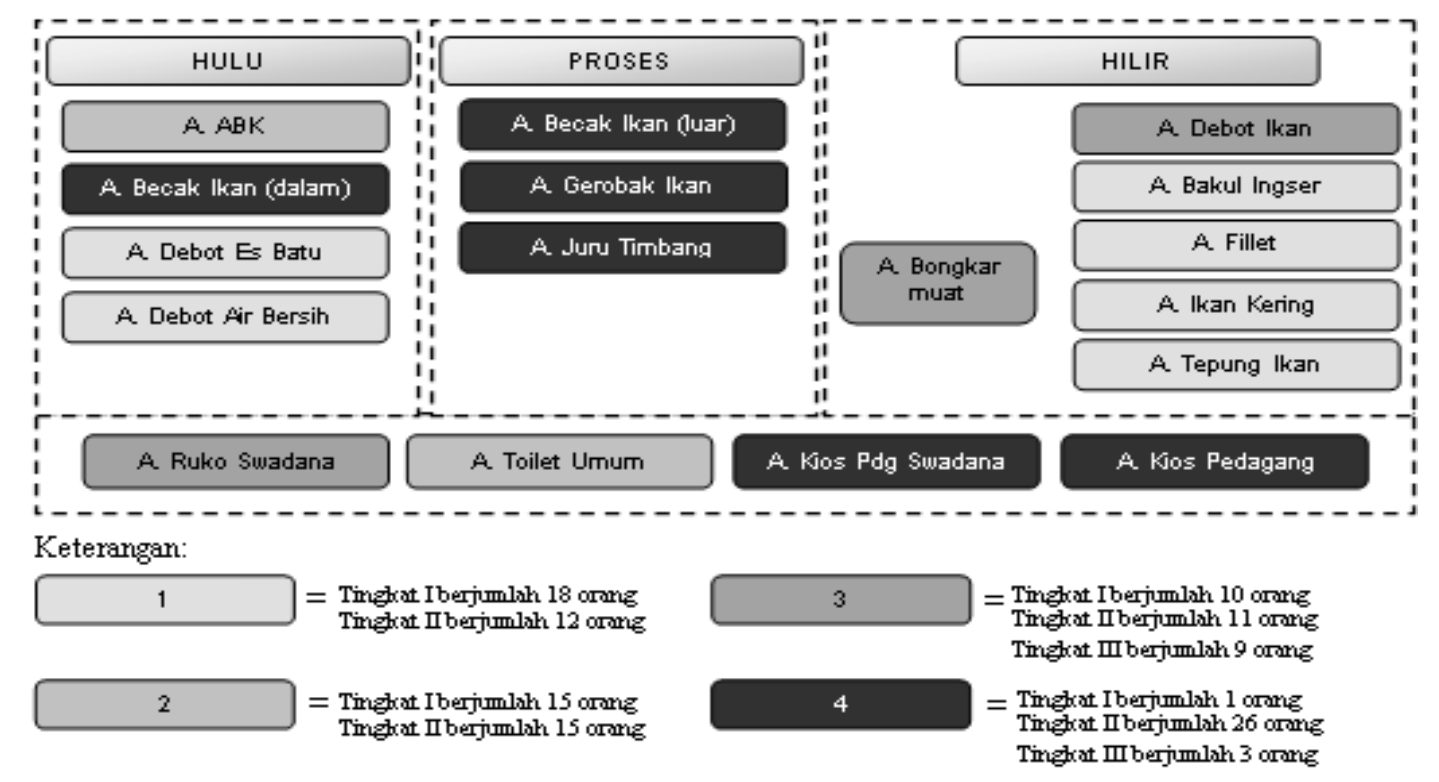

Gambar 5. Tingkat Kesejahteraan Tiap Aktivitas

\section{Analisis Aktivitas Unggulan}

Penentuan aktivitas unggulan yaitu dengan melihat total skor yang didapatkan dari penjumlahan skor analisis sebelumnya. Gambar 6 menunjukkan aktivitas unggulan di PPP Tegalsari. Hasil analisis menunjukan bahwa aktivitas pelayanan jasa menjadi aktvitas menjadi aktivitas unggulan di PPP Tegalsari dengan total skor berjumlah 14 di dapat dari analisis rata-rata pendapatan, kesempatan menabung, analisis kesempatan bekerja, dan tingkat kesejahteraan pekerja.

Nilai pada Gambar 6 menunjukan jumlah skor yang dipeoleh setiap aktivitas berdasarkan analisis yang telah dilakukan sebelumnya. Terlihat pada gambar aktiitas pelayanan jasa memiliki total nilai tertinggi yaitu aktivitas becak ikan dan gerobak ikan sebesar 14 poin serta aktivitas juru timbang sebesar 13 poin. Analisis aktivitas unggulan memperlihatkan persebaran yang tidak merada jika dilihat dari sudut pandang analisis yang telah dilakukan sebelumnya yaitu rata-rata pendapatan, kesempatan menabung, kesempatan bekerja, serta kesejahteraan. Terlihat pada gambar di atas menunjukan aktivitas dengan warna merah muda yang berarti kategori rendah justru memiliki jumlah lebih banyak dan tersebar merata di setiap sektor aktivitas dari hulu hinga hilir. Kiranya analisis tersbut bisa menjadi sebuah pertimbangan karena fakta di lapangan kesejahteraan pekerja tidak merata di setiap sektor aktivitas di dalam PPP Tegalsari. 


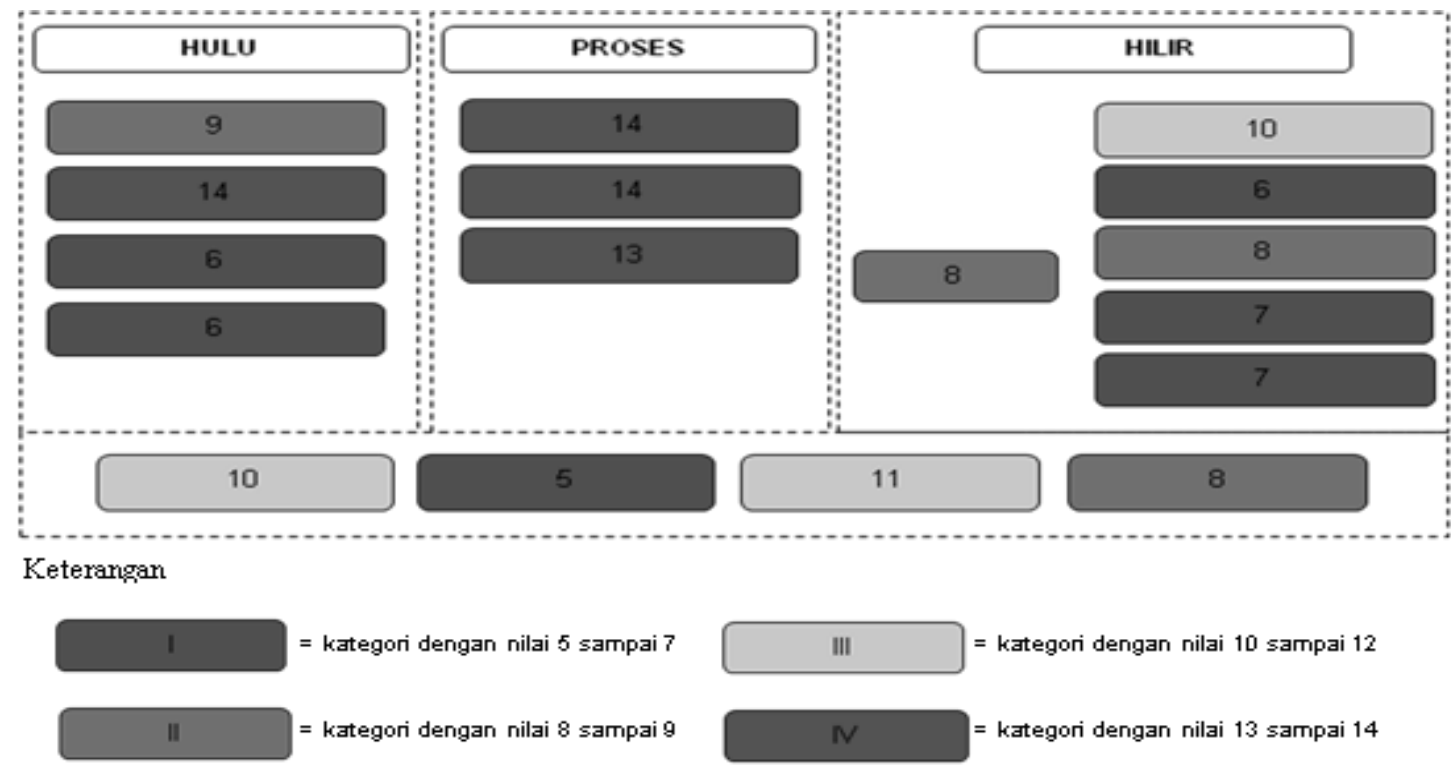

\section{Gambar 6. Aktivitas Unggulan}

\section{Analisis Pengaruh PPP Tegalsari Terhadap Kesejahteraan Pekerja Pelabuhan}

Analisis dilakukan dengan membandingkan tingkat kesejahteraan pekerja pada saat awal Tahun 1900an/awal bekerja dengan tingkat kesejahteraan pada saat sekarang. Pengambilan waktu awal adalah tahun 1990 karena pada tahun tersebut dapat terlihat perbedaan kesejahteraan pekerja dengan jelas sedangkan awal bekerja diambil untuk mengakomodir responden yang baru bekerja setelah tahun 1990an. Setelah analisis dilakukan terdapat perbedaan yang sangat signifikan kesejahteraan pekerja pada awal bekerja dengan kesejahteraan pada saat sekarang. Analisis tersebut juga dapat menjawab pertanyaan penelitian bahwa keberadaan PPP Tegalsari dapat memberikan peningkatan kesejahteraan bagi pekerja pelabuhan, walaupun tingkat kesejahteraan tidak tersebar merata di seluruh aktivitas. Penjelasan perubahan tingkat kesejahteraan pekerja berdasarkan 13 indikator kesejahteraan dilihat pada penjelasan Tabel 2.

Tabel 2. Perbedaan Rata-rata Indikator Kesejahteraan

\begin{tabular}{|c|c|c|c|c|c|c|c|c|c|c|c|c|c|c|}
\hline \multirow[b]{2}{*}{ No } & \multicolumn{3}{|c|}{$\begin{array}{c}\text { Aktivitas } \\
\text { Pelayanan Jasa }\end{array}$} & \multicolumn{3}{|c|}{$\begin{array}{c}\text { Aktivitas } \\
\text { Perdagangan }\end{array}$} & \multicolumn{3}{|c|}{$\begin{array}{c}\text { Aktivitas Pekerja } \\
\text { Penggiat Usaha } \\
\text { Perikanan } \\
\end{array}$} & \multicolumn{3}{|c|}{$\begin{array}{l}\text { Aktivitas } \\
\text { Penunjang }\end{array}$} & \multicolumn{2}{|c|}{$\begin{array}{c}\text { Total } \\
\text { keseluruhan }\end{array}$} \\
\hline & 胥 & $\begin{array}{l}\frac{\pi}{0} \\
\frac{\pi}{0} \\
\text { ñ }\end{array}$ & $\frac{5}{5}$ & 要 & $\frac{\frac{\pi}{0}}{\frac{\pi}{0}}$ & $\begin{array}{l}\frac{5}{\overline{2}} \\
\frac{2}{2} \\
\text { ஸे }\end{array}$ & 吾 & $\frac{\frac{\pi}{0}}{\frac{\pi}{0}}$ & $\frac{5}{\frac{\pi}{2}}$ & 胥 & $\begin{array}{l}\frac{\pi}{0} \\
\frac{0}{0} \\
\omega\end{array}$ & $\frac{5}{\frac{\pi}{2}}$ & 吾 & $\frac{\frac{\pi}{0}}{\frac{0}{0}}$ \\
\hline 1 & 80 & 145 & 65 & 67 & 97 & 30 & 43 & 79 & 36 & 96 & 112 & 16 & 286 & 433 \\
\hline 2 & 64 & 121 & 57 & 42 & 80 & 38 & 38 & 63 & 25 & 76 & 112 & 36 & 220 & 376 \\
\hline 3 & 82 & 118 & 36 & 103 & 115 & 12 & 83 & 124 & 41 & 84 & 121 & 37 & 352 & 478 \\
\hline 4 & 89 & 119 & 30 & 98 & 110 & 12 & 95 & 121 & 26 & 103 & 120 & 17 & 385 & 470 \\
\hline 5 & 95 & 118 & 23 & 89 & 114 & 25 & 81 & 108 & 27 & 85 & 119 & 34 & 350 & 459 \\
\hline 6 & 95 & 116 & 21 & 98 & 114 & 16 & 79 & 118 & 39 & 94 & 122 & 28 & 366 & 470 \\
\hline 7 & 91 & 128 & 37 & 78 & 116 & 38 & 83 & 125 & 42 & 81 & 118 & 37 & 333 & 487 \\
\hline
\end{tabular}




\begin{tabular}{|c|c|c|c|c|c|c|c|c|c|c|c|c|c|c|}
\hline \multirow{2}{*}{ No } & \multicolumn{3}{|c|}{$\begin{array}{c}\text { Aktivitas } \\
\text { Pelayanan Jasa }\end{array}$} & \multicolumn{3}{|c|}{$\begin{array}{c}\text { Aktivitas } \\
\text { Perdagangan }\end{array}$} & \multicolumn{3}{|c|}{$\begin{array}{c}\text { Aktivitas Pekerja } \\
\text { Penggiat Usaha } \\
\text { Perikanan }\end{array}$} & \multicolumn{3}{|c|}{$\begin{array}{c}\text { Aktivitas } \\
\text { Penunjang }\end{array}$} & \multicolumn{2}{|c|}{$\begin{array}{c}\text { Total } \\
\text { keseluruhan }\end{array}$} \\
\hline & 疍 & $\begin{array}{l}\frac{\pi}{0} \\
\frac{\pi}{0} \\
\text { ñ }\end{array}$ & $\begin{array}{l}\frac{5}{5} \\
: \frac{2}{D} \\
\end{array}$ & $\frac{\pi}{3}$ & $\frac{\frac{\pi}{0}}{\frac{\pi}{0}}$ & $\begin{array}{l}\frac{5}{5} \\
: \frac{1}{D} \\
\end{array}$ & 疍 & $\frac{\frac{\pi}{0}}{\frac{\pi}{0}}$ & 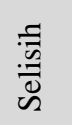 & 胥 & $\frac{\frac{\pi}{0}}{\frac{\pi}{0}}$ & 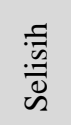 & 胥 & $\frac{\frac{\pi}{\pi}}{\frac{\pi}{0}}$ \\
\hline 8 & 88 & 119 & 31 & 78 & 113 & 35 & 74 & 107 & 33 & 84 & 109 & 25 & 324 & 448 \\
\hline 9 & 86 & 105 & 19 & 99 & 117 & 18 & 101 & 115 & 14 & 93 & 108 & 15 & 379 & 445 \\
\hline 10 & 98 & 128 & 30 & 82 & 120 & 38 & 98 & 121 & 23 & 94 & 126 & 32 & 372 & 495 \\
\hline 11 & 72 & 62 & -10 & 76 & 67 & -9 & 59 & 91 & 32 & 68 & 68 & 0 & 275 & 288 \\
\hline 12 & 69 & 125 & 56 & 67 & 113 & 46 & 63 & 114 & 51 & 65 & 124 & 59 & 264 & 476 \\
\hline 13 & 51 & 91 & 40 & 59 & 87 & 28 & 64 & 75 & 11 & 74 & 86 & 12 & 248 & 339 \\
\hline Total & 1060 & 1495 & 435 & 1036 & 1363 & 327 & 961 & 1361 & 400 & 1097 & 1445 & 348 & 4136 & 5664 \\
\hline
\end{tabular}

* Awal = Pada awal Tahun 1990an/awal bekerja

* Setelah $=$ Pada saat sekarang

Berdasarkan penjelasan Tabel 2 bahwa aktivitas pelayanan jasa adalah aktivitas yang memiliki dampak pengaruh terhadap kesejahteraan, sedangkan aktivitas perdagangan menjadi aktivitas dengan dampak paling kecil. Berdasarkan 13 indikator kesejahteraan, indikator kemampuan untuk mendapatkan akses bantuan menjadi indikator yang paling rendah. Hal tersebut berarti kemudahan untuk mendapatkan bantuan menjadi salah satu indikator yang belum terpenuhi secara meneyuluh di setiap aktivitas.

Indikator pendapatan menjadi indikator yang memiliki peningkatan terbesar pada aktivitas pelayanan jasa. Hal tersebut dikarenakan terbatasnya jumlah pekerja pada sektor ini mengakibatkan nilai jual jasa yang mereka tawarkan semakin meningkat setiap tahunnya. Terlihat pada tabel 2 bahwa indikator pendapatan pada aktivitas perdagangan dan aktivitas pekerja penggiat usaha perikanan tidak termasuk kedalam golongan sangat baik. Hal tersebut berbeda dengan aktivitas pelayanan jasa dan penunjang.

Aktivitas di dalam kawasan PPP Tegalsari terbagi menjadi 4 kelompok, yaitu aktivitas pelayanan jasa, aktivitas perdagangan, aktivitas pekerja penggiat usaha perikanan, dan aktivitas penunjang. Rata-rata pendapatan responden disetiap aktivitasnya yaitu pelayanan jasa Rp 5.240.000,00, pada aktivitas penunjang Rp 3.787.333,00, pada aktivitas perdagangan Rp 2.381.667,00, pada aktivitas pe-kerja penggiat usaha perikanan berjumlah $\mathrm{Rp}$ 1.811.667,00. Selisih antara pendapatan dan pengeluaran untuk aktivitas pelayanan jasa berjumlah $\mathrm{Rp}$ 2.276.667,00, aktivitas penunjang berjumlah $\mathrm{Rp}$ 1.266.667, aktivitas perdagangan memiliki jumlah sebesar Rp 758.333,00, dan pada aktivitas pekerja penggiat usaha perikanan memiliki selisih sebesar Rp 261.667,00.

Kesempatan bekerja bagi masyarakat sekitar di dalam aktivitas pelayanan jasa sebesar 98\%, aktivitas pekerja penggiat usaha perikanan sebesar 93\%, aktivitas perdagangan sebesar $84 \%$, dan aktivitas penunjang sebesar $16 \%$. Berdasarkan tingkat kesejahteraan aktivitas pelayanan jasa berada di posisi teratas dengan nilai 4 , aktivitas penunjang dengan nilai 3 , aktivitas perdagangan dengan nilai 2 , dan aktivitas pekerja penggiat usaha perikanan dengan nilai 1 . Aktivitas unggulan dengan perolehan skor tertinggi yaitu 16 adalah aktivitas pelayanan jasa. Diikuti oleh aktivitas penunjang dengan nilai 10 , aktivitas perdagangan dengan nilai 8 , dan terakhir aktivitas pekerja penggiat usaha perikanan dengan nilai 6 .

Berdasarkan analisis pengaruh Pelabuhan Perikanan Pantai Tegalsari terhadap kesejahteraan pekerja, aktivitas yang memiliki pengaruh paling tinggi terhadap kesejahteraan pekerja adalah aktivitas pelayanan jasa dengan nilai sebesar 435. Disusul oleh aktivitas pekerja penggiat usaha perikanan dengan nilai sebesar 400, aktivitas perdagangan dengan nilai 363, dan aktivitas penunjang dengan nilai sebesar 348 . Kondisi 
ini menunjukkan bahwa berbagai aktivitas dalam kegiatan perikanan bernilai untuk peningkatan kesejahteraan pekerja. Temuan ini sejalan bahwa aktivitas perikanan mampu menggerakkan perekonomian dan memenuhi kesejahteraan nelayan dan keluarganya (Rees et al., 2013).

\section{Kesimpulan dan Rekomendasi}

\section{Kesimpulan}

Keberadaan PPP Tegalsari berpengaruh terhadap kesejahteraan para pekerja walaupun persebaran tingkat kesejahteraan pekerja tidak merata di setiap sektor aktivitas pekerja. Aktivitas di dalam kawasan PPP Tegalsari terbagi menjadi 4 kelompok, yaitu aktivitas pelayanan jasa, aktivitas perdagangan, aktivitas pekerja penggiat usaha perikanan, dan aktivitas penunjang. Aktivitas tersebut dapat dimasukan kedalam alur aktivitas huluhilir pelabuhan dimana aktivitas pelayanan jasa tersebar pada aktivitas hulu dan proses sebelum hilir. Aktivitas penggiat usaha periakanan terfokus pada aktivitas hilir. Aktivitas penunjang terdapat merata pada aktivitas hulu dan hilir karena aktivitas perdagangan termasuk di dalamnya untuk memenuhi kebutuhan melaut serta menjual hasil perikanan. Aktivitas penunjang berperan sebagai aktivitas yang membantu proses berjalannya aktivitas hulu-hilir di dalam pelabuhan. Hal ini menunjukkan bahwa setiap aktivitas yang terjadi di PPP Tegalsari memiliki dampak ekonomi berbeda bagi para pekerjanya ditandai dengan indikator pendapatan. Pendapatan adalah indikator yang paling mempengaruhi terhadap tingkat kesejahteraan pekerja pelabuhan. Pendapatan berbanding lurus dengan tingkat kesejahteraan pekerja, semakin tinggi pendapatan maka semakin tinggi tingkat kesejahteraan pekerja. Begitu juga sebaliknya, untuk aktivitas pekerja penggiat usaha perikanan dan aktivitas perdagangan dengan pendapatan yang tidak sama aktivitas penunjang dan pelayanan jasa memiliki tingkat kesejahteraan yang rendah.

\section{Rekomendasi}

Berdasarkan temuan studi terdapat beberapa rekomendasi yang harus diperhatikan terutama oleh pihak pemerintah dan pengusaha atau swasta

1. Pemerintah

- Aktivitas unggulan di dalam kawasan pelabuhan adalah aktivitas pelayanan jasa karena memiliki nilai tertinggi, pemerintah diharapkan dapat memaksimalkan aktivitas tersebut guna mengembangkan PPP Tegalsari agar lebih besar sehingga peluang kerja daalam aktivitas pelayanan jasa juga semakin besar terutama memprioritaskan masyarakat yang berawsal dari daerah sekitar.

- Aktvitas pekerja penggiat usaha perikanan memiliki skor terendah dalam analisis, hal tersebut dapat dijadikan perhatian bagi pemerintah agar lebih peduli kepada pekerja pada sektor ini. Seperti contohnya adalah pendapatan yang lebih tinggi sehingga dapat meningkatkan kesempatan menabung dan juga meningkatkan tingkat kesejahteraan pekerja.

- Pemberian modal kepada masyarakat sekitar agar aktivitas pada sektor penunjang dapat lebih berkembang dan tidak dikuasai dari masyarakat luar daerah sehingga dapat meningkatkan lapangan pekerjaan dan kesejahteraan bagi masyarakat sekitar.

- Selama ini hasil sumber daya laut Kota Tegal dikirim keluar daerah masih dalam bentuk mentah. Sehingga pembangunan komplek industri hilir yang terintegrasi dengan TPI dapat menciptakan lapangan pekerjaan dan juga pengawasan retsibusi yang lebih terkontrol. 


\section{Pengaruh Pelabuhan Perikanan Pantai Tegalsari terhadap Kesejahteraan Pekerja}

- Perlu ada relokasi kawasan industri yang berdekatan dengan permukiman guna mencapai kesehatan lingkungan.

2. Pengusaha/Pihak swasta

- Memperhatikan kesejahteraan pekerja sudah menjadi kewenangan pemilik usaha. Untuk itu diharapkan lebih transparan dalam hal keuntungan, sehingga pekerja dapat maksimal dalam hal pendapatan yang selayaknya mereka dapatkan untuk mencukupi kebutuhan dan menabung.

- Keselamatan pekerja pada saat bekerja hendaknya lebih dipentingkan, berdasarkan pengamatan masih banyaknya pekerja yang tidak menggunakan pelingung diri maksimal seperti contohnya masker, topi, atau pakaian khusus bekerja.

- Kesadaran para pemilik kapal harus lebih ditingkatkan untuk membayar kewajibannya yaitu retribusi kepada petugas TPI sehingga dapat meningkat pendapatan daerah.

\section{Daftar Pustaka}

Amarasinghe, O. (2005). Social welfare and social security in Sri Lanka fisheries. Retrieved from http://aquaticcommons.org/247/1/Sri_Lanka_Social_Security.pdf.

BPS (Badan Pusat Statistik) Republik Indonesia. (2011). Statistik pendapatan rumah tangga usaha perikanan 2011. Indonesia: Badan Pusat Statistik Indonesia.

Eggert, H. \& Greaker M. (2009). Effects of global fisheries on developing countries possibilities for income and threat of depletion. Environment for Development, EfD DP 09-02. Retrieved from http://www.rff.org/files/sharepoint/WorkImages/Download/EfD-DP-09-02.pdf.

Johnsen, J. P., \& Vik, J. (2013). Pushed or pulled? Understanding fishery exit in a welfare society context. Springer Maritime Studies, 12(4), 1-20. doi:10.1186/2212-9790-12-4.

McEvoy, D. M., Brandt, S., Lavoie, N., \& Anders, S. (2009). The effects of ITQ management on fishermen's welfare when the processing sector is imperfectly competitive. Land Economics, 85(3), 470-484. doi:10.3368/le.85.3.470.

Nurdyana, E., Rosyid, A., \& Boesono, H. (2013). Strategi peningkatan pemanfaatan fasilitas dasar dan fungsional Pelabuhan Perikanan Pantai (PPP) Tegalsari Kota Tegal. Journal of Fisheries Resources Utilization Management and Technology, 2(2), 35-45.

Pass, C., \& Lowes, B. (1994). Kamus lengkap ekonomi (Tumpul Rumpea dan Posman Haloho, Trans.). Jakarta: Erlangga.

Rees, S. E., Rodwell, L. D., Searle, S., \& Bell, A. (2013). Identifying the issues and options for managing the social impacts of Marine Protected Areas on a small fishing community. Fisheries Research, 146, 51-58. doi:10.1016/j.fishres.2013.04.003.

Rustam. (2002). "Pendapatan menurut standar akuntansi keuangan No. 23." Retrieved from http://library.usu.ac.id/download/fe/akuntansi-rustam2. 25 Januari 2002.

Standing, A. (2008). Corruption and industrial fishing in Africa. U4 Anti-Corruption Resource Centre. U4 ISSUE 2008. Retrieved from http://www.cmi.no/publications/file/3189-corruption-and-commercial-fisheriesin-africa.pdf.

Suherman, A., \& Dault, A. (2009). Dampak sosial ekonomi pembangunan dan pengembangan Pelabuhan Perikanan Nusantara (PPN) pengambangan Jembrana Bali. Jurnal Saintek Perikanan, 4(2), 24-32.

Suherman, A. (2010). Alternatif pengembangan Pelabuhan Perikanan Nusantara Brondong Lamongan Jawa Timur. Jurnal Saintek Perikanan, 5(2), 65-72.

Sugiyono. (2008). Metode penelitian kuantitatif, kualitatif dan $R \& D$. Bandung: Alfabeta.

Sukirno, S. (2000). Makro ekonomi modern. Jakarta: PT Rajawali Persada.

Yahya, E., Rosyid, A., \& Suherman, A. (2012). Tingkat pemanfaatan fasilitas dasar dan fungsional dalam strategi peningkatan produksi di Pelabuhan Perikanan Pantai Tegalsari Kota Tegal Jawa Tengah. Journal of Fisheries Resources Utilization Management and Technology, 2(1), 56-65. 